University of New Orleans

ScholarWorks@UNO

$12-2001$

\title{
Deconvolution of Chirp Sidescan Sonar Data
}

Juliette W. loup

University of New Orleans

Maria T. Kalcic

Dale Bibee

Edit J. Kaminsky

University of New Orleans, ejbourge@uno.edu

George E. loup

University of New Orleans

Follow this and additional works at: https://scholarworks.uno.edu/ee_facpubs

Part of the Electrical and Electronics Commons

\section{Recommended Citation}

loup, J., E. Kaminsky, M. Kalcic, and G. loup, "Deconvolution of Chirp Sidescan Sonar Data," 142nd ASA Meeting, Ft. Lauderdale, FL, 3-7 Dec. 2001. J. Acoustical Soc. of America, Vol 110, No.5, pt. 2, pp. 2740, Nov. 2001.

This Article is brought to you for free and open access by the Department of Electrical Engineering at ScholarWorks@UNO. It has been accepted for inclusion in Electrical Engineering Faculty Publications by an authorized administrator of ScholarWorks@UNO. For more information, please contact scholarworks@uno.edu. 


\section{Acoustical Society of America}

\section{The Journal of the Acoustical Society of America}

Deconvolution of chirp sidescan sonar data

Juliette W. Ioup ${ }^{1}$, Maria T. Kalcic ${ }^{2}$, L. Dale Bibee ${ }^{2}$, Edit J. Kaminsky ${ }^{3}$ and George E. loup ${ }^{3}$ J. Acoust. Soc. Am. 110, 2740 (2001); http://dx.doi.org/10.1121/1.4777528

\section{Abstract}

The first return of a sidescan sonar chirp contains information about the bottom and immediate subbottom character and roughness. Measured real data from a chirp sidescan sonar are basebanded, producing complex signals. These signals are deconvolved using an ideal transmitted source signal, a measured source signal, and, for cross-correlated data, the autocorrelation of the source. Four deconvolution techniques are used: (1) Fourier division in the frequency domain; (2) a least squares technique in the time domain; (3) the reblurring iterative deconvolution method of Kawata and Ichioka (which by definition uses the autocorrelation of the source); and (4) an alternativ always-convergent modification of van Cittert iterative deconvolution. The deconvolved signals are compared to the cross-correlation of the source with the received signal (matched filter) without deconvolution. Results are discussed in relation to the known bottom characteristics. [Research supported in part by an NRL/ASEE Summer Faculty Fellowship and ONR.]

(C) 2001 Acoustical Society of America

DOI: http://dx.doi.org/10.1121/1.4777528

\section{Key Topics}

Deconvolution

Chirping

Sonar

Fellowships

\section{Most read this month}

Evaluation of smartphone sound measurement applications ${ }^{a)}$

Chucri A. Kardous and Peter B. Shaw 
Low frequency, ca. $40 \mathrm{~Hz}$, pulse trains recorded in the humpback whale assembly in Hawaii

James D. Darling

Coffee roasting acoustics

Preston S. Wilson

\section{Most cited this month}

Theory of Propagation of Elastic Waves in a Fluid-Saturated Porous Solid. I. Low-Frequency Range

M. A. Biot

Transformed Up-Down Methods in Psychoacoustics

H. Levitt

Theory of Propagation of Elastic Waves in a Fluid-Saturated Porous Solid. II. Higher Frequency Range

M. A. Biot

\section{Recently Viewed Content}

Deconvolution of chirp sidescan sonar data

Sub-bottom profiling using time-frequency analysis 